\title{
Phytonutrients of Bitter Apricot Seeds Modulate Human Lipid Profile and LDL Subfractions in Adults with Elevated Cholesterol Levels
}

\author{
Jana Kopčeková ${ }^{1, *(\mathbb{D})}$, Anna Kolesárová ${ }^{2}$, Marianna Schwarzová ${ }^{1}$, Anton Kováčik ${ }^{3}{ }^{\mathbb{C}}$, Jana Mrázová ${ }^{1}$, \\ Martina Gažarová ${ }^{1} \mathbb{D}$, Petra Lenártová ${ }^{1}$, Peter Chlebo ${ }^{1}$ and Adriana Kolesárová ${ }^{3}$
}

Citation: Kopčeková, J.; Kolesárová, A.; Schwarzová, M.; Kováčik, A.;

Mrázová, J.; Gažarová, M.; Lenártová, P.; Chlebo, P.; Kolesárová, A. Phytonutrients of Bitter Apricot Seeds Modulate Human Lipid Profile and LDL Subfractions in Adults with Elevated Cholesterol Levels. Int. J. Environ. Res. Public Health 2022, 19, 857. https://doi.org/10.3390/ ijerph19020857

Academic Editor: Anna M. Giudetti

Received: 12 November 2021

Accepted: 11 January 2022

Published: 13 January 2022

Publisher's Note: MDPI stays neutral with regard to jurisdictional claims in published maps and institutional affiliations.

Copyright: (C) 2022 by the authors. Licensee MDPI, Basel, Switzerland. This article is an open access article distributed under the terms and conditions of the Creative Commons Attribution (CC BY) license (https:// creativecommons.org/licenses/by/ $4.0 /)$.
1 Institute of Nutrition and Genomics, Faculty of Agrobiology and Food Resources, Slovak University of Agriculture in Nitra, 94976 Nitra, Slovakia; marianna.schwarzova@uniag.sk (M.S.); jana.mrazova@uniag.sk (J.M.); martina.gazarova@uniag.sk (M.G.); petra.lenartova@uniag.sk (P.L.); peter.chlebo@uniag.sk (P.C.)

2 Institute of Food Sciences, Faculty of Biotechnology and Food Sciences, Slovak University of Agriculture in Nitra, 94976 Nitra, Slovakia; anna.kolesarova@uniag.sk

3 Institute of Applied Biology, Faculty of Biotechnology and Food Sciences, Slovak University of Agriculture in Nitra, 94976 Nitra, Slovakia; anton.kovacik@uniag.sk (A.K.); adriana.kolesarova@uniag.sk (A.K.)

* Correspondence: jana.kopcekova@uniag.sk; Tel.: +421-37-641-4225

\begin{abstract}
The objective of the present study was to evaluate the effect of short-term consumption of bitter apricot seeds phytonutrients on cardiovascular risk factors with a special focus on LDL cholesterol subfractions using the Lipoprint system. A group of 34 adult volunteers (21 female/13 male) consumed $60 \mathrm{mg} \mathrm{kg}^{-1}$ of body weight of bitter apricot seeds daily for 42 days. Subjects were divided into two groups: one with normal cholesterol levels (NTC) and one with elevated total cholesterol levels (ETC). Blood serum levels of total cholesterol (T-C), low-density cholesterol (LDL-C), highdensity cholesterol (HDL-C), and triglycerides (TG) did not change significantly $(p>0.05)$ in NTC group. However, there were significant decreasing of T-C $(p<0.05)$ and LDL-C $(p<0.01)$ in ETC group. The $\mathrm{LDL}_{1}, \mathrm{LDL}_{2}$, and atherogenic $\mathrm{LDL}_{3-7}$ subfractions progressively decreased after 42 days of apricot seeds consumption in ETC group $(p<0.05)$. Apricot seeds consumption was associated with a significant increase in the mean LDL particle size especially in ETC group $(p<0.01)$. The results of the present study support the hypothesis that daily consumption of bitter apricot seeds for 42 days positively modified the lipoprotein profile in the group with elevated total cholesterol.
\end{abstract}

Keywords: apricot seeds; phytonutrients; lipid profile; cholesterol; LDL subfractions

\section{Introduction}

Cardiovascular disease (CVD) remains the world's leading cause of morbidity and mortality [1,2]. Atherosclerosis is the dominant cause of cardiovascular disease [3], including myocardial infarction (MI), heart failure, stroke, and claudication [4]. Atherosclerosis is a multifactorial disease that is thought to be primarily inflammatory in origin [5]. The pathogenesis of atherosclerosis involves a complex interplay of endothelial dysfunction, inflammation, lipid accumulation, vascular smooth muscle cell proliferation, matrix transformation and calcification, and persistent inflammation and ultimately leads to the formation of atherosclerotic plaque [2,6-8].

A major risk factor for CVD is dyslipidemia, which occurs mainly in adults worldwide and is defined as an abnormal blood lipids level [9]. Dyslipidemia is characterized by elevated levels of low-density lipoproteins (LDL-C), small and very low-density lipoproteins (VLDL), and intermediate-density lipoproteins (IDL), triglyceride (TG), and low serum levels of high-density lipoprotein cholesterol (HDL-C) and its lipoprotein subfractions, which correlate with an increased risk for CVD [10-13]. Hypercholesterolemia was reported as the highest attributable risk factor for atherosclerosis and subsequent coronary heart 
disease (CHD) in a given population. Although increased LDL-C is considered a major risk factor for cardiovascular disease [14,15], a number of cardiac events occur in people without clinically abnormal LDL-C concentrations [16]. The atherogenic potential of LDL particles is not just associated to their concentration but also to their heterogeneity with regard to lipid composition, particle size, and density [17].

In recent decades, lipoprotein research has focused on the characterization of atherogenic and non-atherogenic lipoprotein profiles [18]. This may be due to the fact that lipoprotein particles consist of a heterogeneous group of subfractions differing not only in size and density but also in chemical composition and physiological function [19-21]. In the presence of the seven fractions of LDL cholesterol, which important for the distribution on anti-atherogenic fractions $\mathrm{LDL}_{1-2}$ and atherogenic small dense lipoproteins $\mathrm{LDL}_{3-7}$ (sdLDL), their role in the pathogenesis of coronary atherosclerosis was confirmed [22,23]. Studies have demonstrated that the concentration of sdLDL was positively correlated with the incidence of CVD [24]. Smaller and denser LDL particles are considered as an atherogenic risk factor for CVD due to their greater tendency to oxidize and their permeability through the endothelium of arterial walls [22,25]. Large LDL particles (diameter $\geq 25 \mathrm{~nm}$ ) are considered a non-atherogenic phenotype (pattern A) and small, dense LDL particles with sizes 19.0-20.5 nm are considered an atherogenic phenotype (pattern B) [26,27]. Monitoring and control of LDL-C and HDL-C levels is considered necessary to reduce the risk of cardiovascular disease [28].

The diet is an important determinant of serum cholesterol, but dietary cholesterol has only a modest contribution to plasma concentrations of LDL-C [29]. Diet can affect CVD directly by modulating the composition of vascular plaques and indirectly by affecting the rate of aging [30]. Previous epidemiological studies indicate that high consumption of foods rich in bioactive compounds has a positive effect on human health and could diminish the risk of numerous diseases, such as cancer, heart disease, stroke, Alzheimer's, diabetes, cataracts, and age-related functional decadence [31,32]. Phytonutrients or phytochemicals are natural bioactive compounds obtained from plants that perform specific biological activities and modify different physiological functions to improve general human health $[33,34]$. They have specific pharmacological effects that may affect aging, allergies, antioxidant defense, blood pressure, bones, cancer, the central nervous system, diabetes, the gastrointestinal tract, immunity, inflammation, lipidemia, the liver, microbes, pain, and much more [35].

Bitter apricot seeds are important source of phytochemicals with strong chemopreventive activity [36,37]. They contain phenolic compounds, terpenoids, oil, and bioactive proteins and peptides [37] and exhibited higher antioxidative activity than flesh of the fruit [38]. The use of bitter apricot seeds in human nutrition is limited compared to sweet seeds due to the content of the toxic, cyanogenic glycoside amygdalin [39]. Various pharmacological studies demonstrated anti-inflammatory [40], anti-asthmatic [41,42], analgesic, anti-mutagenic [36], anti-tussive [43], antioxidant [36,44-46], anti-cancer [44,47-56], and anti-microbial [36,45] effects of apricot seeds. Our previous reports described the effects of bitter apricot seeds consumption on body composition, blood serum lipids, and other risk factors for CVD [57] in healthy volunteers. This study is the first trial to evaluate the effects of short-term consumption of bitter apricot seeds phytonutrients on cardiovascular risk factors, with a special focus on LDL cholesterol subfractions of adults with elevated cholesterol levels.

\section{Materials and Methods}

\subsection{Participants and Study Design}

A group of 34 adult volunteers (21 female/13 male; mean age $38.91 \pm 10.77$ years) participated in a 6-week interventional program. Subjects were divided into two groups: those with normal cholesterol levels, i.e., NTC (total cholesterol $<5.0 \mathrm{mmol} / \mathrm{L}, 7 \mathrm{male}$ and 14 female; average age $36.05 \pm 7.85$ ), and those with elevated total cholesterol levels, 
i.e., ETC (total cholesterol $\geq 5.0 \mathrm{mmol} / \mathrm{L}, 6$ male and 7 female; average age $43.54 \pm 13.38$ ) in order to evaluate the individual influence of bitter apricot seeds on the blood lipid profile.

The volunteers had to meet the following inclusion criteria: willingness to participate in a 6-week interventional program, apparently healthy women and men, age 20-60 years, stable body weight $( \pm 3 \mathrm{~kg})$ during the last 3 months, and alcohol consumption $\leq 30 \mathrm{~g} /$ day. Exclusion criteria included an inability to give informed consent; use of cholesterol lowering medications or supplements; chronic diseases (i.e., cardiovascular diseases, diabetes, inflammatory diseases, cancer, allergy); thyroid abnormalities; active liver disease; use of hypolipidemics, corticosteroids, etc.; pregnancy or plans to become pregnant during the study and breastfeeding; tobacco, alcohol, or drug addiction; no intake of any nutritional supplements (vitamins, minerals, antioxidants, and flavonoids); or parallel participation in other dietary intervention study.

A written informed consent was obtained from all the participants prior to their involvement in the study. They were informed of all risks, discomforts, and benefits. This study was conducted according to the guidelines of the Declaration of Helsinki and approved by the Ethics Committee at the Specialized Hospital St. Zoerardus Zobor, n. o. Nitra, Slovak Republic (protocol number 030809/2015).

\subsection{Dietary Intervention}

Volunteers consumed $60 \mathrm{mg} / \mathrm{kg}$ of body weight of bitter apricot seeds divided into several daily doses for 42 days period. The subjects were instructed not to change the composition of their usual diet and their nutrition pattern, to consume approximately one seed each hour (by chewing as thoroughly as possible), and drink water after each consumption.

Apricot seeds were supplied by company TRASCO, Ziar nad Hronom, Slovak Republic. Contents of nutrients were determined by the following methods of AOAC [58]: ash (residue after ignition at $535^{\circ} \mathrm{C}$ ), crude protein $(\mathrm{N}$ determined by Kjeldahl method $\times 6.25$ ) using Kjeltec Auto 1030 (Foss, Denmark), fat content by Soxhlet method for fat extraction using Tecator Soxtec System HT6 (Foss, Denmark), and crude fiber by Henneberg-Stohmann method and total sugars by Luff-Schoorl titration. The content of fatty acids as a percentage in crude fat was determined using Agilent 6890 A GC (Agilent Technologies, Wilmington, DE, USA). Mineral content in apricot seeds was determined by atomic absorption spectroscopy using AVANTA analyzer (GBC Scientific Equipment, Braeside, Australia). Thin Layer Chromatography (TLC) was performed for the analysis of amygdalin content in bitter apricot seeds. Polyphenol compounds were determined by Agilent 1260 HPLC-DAD (Agilent Technologies, Wilmington, DE, USA). Composition of apricot seed used in this study is presented in Table 1.

Table 1. Content of nutrients and bioactive compounds of apricot seeds.

\begin{tabular}{|c|c|c|c|c|c|c|c|}
\hline \multicolumn{2}{|c|}{$\begin{array}{c}\text { Organic Content } \\
(\%)\end{array}$} & \multicolumn{2}{|c|}{$\begin{array}{l}\text { Mineral Content } \\
(\mathrm{mg} / 100 \mathrm{~g})\end{array}$} & \multicolumn{2}{|c|}{$\begin{array}{c}\text { Content of Fatty Acids } \\
(\%)\end{array}$} & \multicolumn{2}{|c|}{$\begin{array}{l}\text { Content of Phenolic } \\
\text { Compounds (mg/g) }\end{array}$} \\
\hline Dry matter & 95.9 & $\mathrm{Ca}$ & 177.4 & Oleic acid & 64.5 & Gallic acid & 30.1 \\
\hline Protein & 22.8 & $\mathrm{P}$ & 470.0 & Linoleic acid & 27.1 & Ferulic acid & 2.9 \\
\hline Ash & 2.5 & $\mathrm{Mg}$ & 205.0 & Palmitic acid & 4.6 & Cinnamic acid & 0.9 \\
\hline Starch & 2.3 & $\mathrm{Na}$ & 64.2 & Stearic acid & 1.2 & Genistein & 5.6 \\
\hline Total sugars & 6.3 & $\mathrm{~K}$ & 592.5 & Palmitoleic acid & 0.8 & Rutin & 11.3 \\
\hline Crude fiber & 28.5 & $\mathrm{Fe}$ & 2.5 & SFA & 5.9 & & \\
\hline Amygdalin & 5.8 & $\mathrm{Zn}$ & 5.9 & MUFA & 65.3 & & \\
\hline Oil & 41.3 & Mn & 0.6 & PUFA & 27.1 & & \\
\hline
\end{tabular}

Abbreviations: SFA, saturated fatty acids; MUFA, monounsaturated fatty acids; PUFA, polyunsaturated fatty acids.

We used the 24-h dietary recall, where respondents provides information about the type and quantity of all food and beverages consumed during the previous 24-h period. We evaluated the data using Mountberry nutritional and fitness software (2011, version 1.1) 
(Wellberry, s.r.o., Nitra, Slovak Republic). This software is designed for a complete analysis of food, meals, and recipes based on the composition of the raw ingredients.

Anthropometric parameters, including body weight (BW), waist circumference (WC), waist-hip ratio (WHR), body fat mass (BFM), visceral fat area (VFA), body mass index (BMI); traditional lipid profile, including total cholesterol (T-C), low-density cholesterol (LDL-C), high-density cholesterol (HDL-C), triglycerides (TG), and lipoprotein subfractions (VLDL, IDL-A, IDL-B, IDL-C, LDL $1, \mathrm{LDL}_{2}, \mathrm{LDL}_{3-7}$ ); liver enzymes, including alanine aminotransferase (ALT), aspartate aminotransferase (AST), alkaline phosphatase (ALP), and gamma glutamyl transferase (GGT); and inflammatory response markers, such as high-sensitivity C-reactive protein (hs-CRP) and creatine kinase (CK), were monitored at baseline of apricot seeds consumption (day 0) and after 6 weeks of consumption (day 42 ).

\subsection{Anthropometric Data}

At baseline as well as 6 weeks after of apricot seeds consumption, volunteers were assessed for weight and height using standard procedures. Body height was measured on the outpatient electronical medical scales Tanita WB-300 in the upright standing position, without shoes. Body weight, waist circumference, hip circumference, and body composition (BFM, \%BFM, and VFA) were diagnosed by multi-frequency bioelectrical impedance analysis (MFBIA) by InBody 720 (Biospace Co., Seoul, Korea). The body mass index (BMI) was calculated by dividing the body weight in kilograms by the square of the height in meters. WHR was calculated by dividing the waist measurement by the hip measurement [59].

\subsection{Blood Sample Collection and Clinical Analysis}

Blood samples were obtained at baseline (day 0) and after 6 weeks after (day 42) of apricot seeds consumption. Venous blood from brachial vein of one arm was collected in the morning after $8 \mathrm{~h}$ of fasting in a standard manner using a vacutainer tube containing ethylendiaminetetra-acetic acid (EDTA) $(2.7 \mathrm{~mL})$ and serum gel $(7.5 \mathrm{~mL})$ by a qualified phlebotomist. Whole blood was centrifuged at $3000 \times g$ for $10 \mathrm{~min}$ at $4{ }^{\circ} \mathrm{C}$. Plasma and serum were separated and stored at $-80^{\circ} \mathrm{C}$ until the analyses.

The fasting serum T-C and TG, liver enzymes (ALT, AST, ALP, and GGT), and CK were measured using commercial kits DiaSys (Diagnostic Systems GmbH, Holzheim, Germany) on the Randox RX Monza analyzer (Randox Laboratories Ltd., Crumlin, United Kingdom). HDL-C and hs-CRP were measured by automatic biochemical analyzer Biolis 24i Premium (Tokyo Boeki Machinery Ltd., Tokyo, Japan) using the commercial kit Randox for HDL-C and Diasys for hs-CRP. The LDL-C level was calculated using the Friedewald equation as T-C-HDL-C-(TG/2.2) in mmol/L [60].

The LDL subfractions and mean LDL particle size were determined from plasma using the analyzer Lipoprint ${ }^{\circledR}$ with commercial "Lipoprint LDL Kit" (Quantimetrix Corp., Redondo Beach, CA, USA) according to the procedure provided by the manufacturer. This method uses linear electrophoresis on a nondenaturing polyacrylamide gel to separate and quantify lipoprotein subfractions. This method allows to separate the LDL subfractions ( 1 and 2 are large LDL, and 3-7 subfractions are small dense LDL), very low-density lipoprotein (VLDL) fractions, as well as the intermediate-density lipoprotein (IDL) C, B, and $\mathrm{A}$.

Lipoprint reports LDL phenotype based on particle size as non-atherogenic phenotype A $(\geq 26.8 \mathrm{~nm})$, intermediate phenotype AB $(26.51-26.79 \mathrm{~nm})$, or atherogenic phenotype B $(\leq 26.5 \mathrm{~nm})$.

\subsection{Statistical Analysis}

Statistical analysis was carried out using the Statistica Cz version 10 (TIBCO Software, Inc., Palo Alto, CA, USA) and MS Excel 2007 (Microsoft Corporation, Redmond, WA, USA). Shapiro-Wilk test was used for testing normality. All the data were expressed as the mean \pm standard deviation (SD). We used a paired $t$-test for normally distributed 
variables and Wilcoxon Signed-Ranks Test for not normally distributed variables. Analysis of variables was performed by one-way analysis of variance (ANOVA). ANCOVA test was used to assess if the differences seen in ANOVA persisted after adjustment for body mass index (BMI) and sex. The statistical significance was established at $p<0.05$. For all outcomes, within-group Cohen's $d$ effect sizes were determined by calculating the mean difference between two groups and then dividing the result by the pooled standard deviation.

\section{Results}

A group of 34 adult volunteers ranging in age from 23 to 65 years with a mean age of $38.91 \pm 10.77$ years participated in the present study. Subjects were divided into the following two groups: those with normal cholesterol levels, i.e., NTC (total cholesterol < $5.0 \mathrm{mmol} / \mathrm{L}, 7$ male and 14 female), and those with elevated total cholesterol levels, i.e., ETC (total cholesterol $\geq 5.0 \mathrm{mmol} / \mathrm{L}, 6$ male and 7 female). Characteristics of the study subjects are summarized in Table 2.

Table 2. Baseline characteristics of study participants.

\begin{tabular}{|c|c|c|c|c|}
\hline \multirow{2}{*}{ Parameter } & \multicolumn{2}{|c|}{ NTC $(n=21)$} & \multicolumn{2}{|c|}{$\operatorname{ETC}(n=13)$} \\
\hline & Women $(n=14)$ & Men $(n=7)$ & Women $(n=7)$ & Men $(n=6)$ \\
\hline Age (y) & $37.5 \pm 9.13$ & $33.14 \pm 3.18$ & $45.29 \pm 14.10$ & $41.50 \pm 13.49$ \\
\hline BW (kg) & $60.54 \pm 8.55$ & $81.16 \pm 11.41$ & $66.21 \pm 17.29$ & $91.18 \pm 17.17$ \\
\hline $\operatorname{VFA}\left(\mathrm{cm}^{2}\right)$ & $70.57 \pm 20.60$ & $60.76 \pm 28.96$ & $94.87 \pm 37.21$ & $106.85 \pm 37.76$ \\
\hline $\mathrm{BMI}\left(\mathrm{kg} / \mathrm{m}^{2}\right)$ & $22.00 \pm 2.44$ & $25.68 \pm 3.16$ & $24.70 \pm 4.84$ & $29.19 \pm 3.98$ \\
\hline $\mathrm{T}-\mathrm{C}(\mathrm{mmol} / \mathrm{L})$ & $4.21 \pm 0.57$ & $4.31 \pm 0.51$ & $5.85 \pm 0.64$ & $5.80 \pm 0.61$ \\
\hline HDL-C (mmol/L) & $1.59 \pm 0.33$ & $1.38 \pm 0.29$ & $1.81 \pm 0.41$ & $1.42 \pm 0.23$ \\
\hline LDL-C (mmol/L) & $2.28 \pm 0.49$ & $2.42 \pm 0.45$ & $3.39 \pm 0.38$ & $3.84 \pm 0.43$ \\
\hline $\mathrm{TG}(\mathrm{mmol} / \mathrm{L})$ & $0.75 \pm 0.31$ & $1.15 \pm 0.74$ & $1.42 \pm 0.75$ & $1.21 \pm 0.41$ \\
\hline GLU (mmol/L) & $5.06 \pm 0.42$ & $5.11 \pm 0.12$ & $5.01 \pm 0.46$ & $5.28 \pm 0.79$ \\
\hline
\end{tabular}

Abbreviations: NTC, normal total cholesterol; ETC, elevated total cholesterol; BW, body weight; VFA, visceral fat area; BMI, body mass index; T-C, total cholesterol; HDL-C, high-density cholesterol; LDL-C, low-density cholesterol; TG, triglycerides; GLU, glucose. Data are expressed as mean \pm standard deviation (SD).

\subsection{Effect of Bitter Apricot Seeds Consumption on Anthropometric Characteristics}

The results of anthropometric characteristics (BW, BFM, VFA, and BMI) of the volunteers after six weeks of apricot seeds consumption are shown in Table 3. In the NTC group, we recorded a significant decrease of BW, BFM, and BMI and, on the contrary, in the ETC group, a significant increase in BW, VFA, and BMI $(p<0.05)$ after 42 days of consumption of apricot seeds. The Cohen's $d$ effect sizes of anthropometric characteristics for the change from baseline to week 6 was $<0.1$ for both groups.

Table 3. Anthropometric characteristics of the subjects before and after apricot seeds consumption.

\begin{tabular}{lcccccc}
\hline \multirow{2}{*}{ Parameter } & \multicolumn{2}{c}{ NTC $(\boldsymbol{n}=\mathbf{2 1})$} & \multicolumn{3}{c}{ ETC $(\boldsymbol{n}=\mathbf{1 3})$} \\
& Day 0 & Day 42 & $p$-Value & Day 0 & Day 42 & $p$-Value \\
\hline BW $(\mathrm{kg})$ & $67.41 \pm 13.63$ & $67.04 \pm 13.46$ & 0.0331 & $77.74 \pm 20.98$ & $78.34 \pm 21.39$ & 0.0243 \\
BFM $(\mathrm{kg})$ & $16.27 \pm 5.43$ & $15.79 \pm 5.29$ & 0.0178 & $23.91 \pm 8.67$ & $24.45 \pm 8.95$ & $>0.05$ \\
BFM $(\%)$ & $24.32 \pm 7.02$ & $23.70 \pm 6.82$ & 0.0234 & $30.70 \pm 6.98$ & $31.17 \pm 6.53$ & $>0.05$ \\
VFA $\left(\mathrm{cm}^{2}\right)$ & $67.30 \pm 23.45$ & $65.96 \pm 22.94$ & $>0.05$ & $100.40 \pm 36.40$ & $103.56 \pm 38.25$ & 0.0344 \\
BMI $\left(\mathrm{kg} / \mathrm{m}^{2}\right)$ & $23.22 \pm 3.16$ & $23.10 \pm 3.13$ & 0.0463 & $26.77 \pm 4.87$ & $26.98 \pm 5.02$ & 0.0200 \\
WHR & $0.866 \pm 0.04$ & $0.861 \pm 0.04$ & $>0.05$ & $0.944 \pm 0.08$ & $0.952 \pm 0.07$ & $>0.05$ \\
WC $(\mathrm{cm})$ & $82.0 \pm 7.48$ & $81.77 \pm 7.32$ & $>0.05$ & $96.45 \pm 15.77$ & $96.90 \pm 15.26$ & $>0.05$ \\
\hline
\end{tabular}

Abbreviations: NTC, normal total cholesterol; ETC, elevated total cholesterol; BW, body weight; BFM, body fat mass; VFA, visceral fat area; BMI, body mass index. Data are expressed as mean \pm standard deviation (SD). Paired $t$-test for normally distributed variables.

\subsection{Effect of Bitter Apricot Seeds Consumption on Traditional Blood Serum Lipid Profile and Fasting Glucose}

Lipid profile of subjects at baseline, and at the end of the intervention periods are shown in Table 4. Blood serum levels of T-C, LDL-C, HDL-C, and TG did not change 
significantly $(p>0.05)$ after 42 days of bitter apricot seeds consumption in NTC group (Cohen's $d<0.1)$. However, there was a significant decrease of T-C $(p<0.05)$ and LDLcholesterol $(p<0.01)$ in ETC group after 42 days of apricot seeds consumption. The Cohen's $d$ effect sizes of LDL-C for the change from baseline to week six in NTC group was $<0.1$ and in ETC was 0.701.

Table 4. Lipid profiles and fasting glucose of the subjects before and after apricot seeds consumption (mmol/L).

\begin{tabular}{lcccccc}
\hline \multirow{2}{*}{ Parameter } & \multicolumn{2}{c}{ NTC $(\boldsymbol{n}=\mathbf{2 1})$} & \multicolumn{3}{c}{ ETC $(\boldsymbol{n}=\mathbf{1 3})$} \\
& Day 0 & Day 42 & $\boldsymbol{p}$-Value & Day 0 & Day 42 & $\boldsymbol{p}$-Value \\
\hline T-C & $4.25 \pm 0.54$ & $4.25 \pm 0.65$ & $>0.05$ & $5.83 \pm 0.60$ & $5.48 \pm 0.83$ & 0.0200 \\
LDL-C & $2.33 \pm 0.47$ & $2.33 \pm 0.56$ & $>0.05$ & $3.60 \pm 0.45$ & $3.22 \pm 0.62$ & 0.0045 \\
HDL-C & $1.52 \pm 0.33$ & $1.49 \pm 0.31$ & $>0.05$ & $1.63 \pm 0.39$ & $1.67 \pm 0.54$ & $>0.05$ \\
TG & $0.73(0.56-0.80)$ & $0.78(0.63-0.92)$ & $>0.05$ & $1.31(0.83-1.56)$ & $1.23(0.88-1.62)$ & $>0.05$ \\
GLU & $5.08 \pm 0.35$ & $5.24 \pm 0.57$ & $>0.05$ & $5.13 \pm 0.62$ & $5.25 \pm 0.61$ & $>0.05$ \\
\hline
\end{tabular}

Abbreviations: NTC, normal total cholesterol; ETC, elevated total cholesterol; T-C, total cholesterol; HDL-C, high-density cholesterol; LDL-C, low-density cholesterol; TG, triglycerides; GLU, glucose. Data are expressed as mean \pm standard deviation (SD) or median (interquartile range). Paired $t$-test for normally distributed variables and Wilcoxon Signed-Ranks Test for not normally distributed variables.

\subsection{Effect of Bitter Apricot Seeds Consumption on Lipoprotein Subfractions}

Table 5 presents changes in the distribution of cholesterol in different lipoprotein subfractions and mean LDL particle size in response to the intervention. After 42 days of consumption of apricot seeds, there were significant differences in the IDL-B $(p<0.01)$ and $\mathrm{LDL}_{2}(p<0.05)$ in NTC group. The $\mathrm{LDL}_{1}$ and $\mathrm{LDL}_{2}$ subfractions progressively decreased during the intervention $(p<0.01)$ in ETC group, but there were always significant differences in the atherogenic $\mathrm{LDL}_{3-7}(p<0.05)$. Furthermore, apricot seeds consumption was associated with a significant increase in the mean LDL particle size, especially in ETC group $(p<0.01)$. Cohen's $d$ effect sizes for the change from baseline to week six was small for all lipoprotein subfraction (0.070-0.453) in NTC group. In the ETC group, Cohen's $d$ effect sizes were small for VLDL, IDL-A, IDL-B, and IDL-C; medium for LDL $_{1}(0.715)$ and total LDL (0.626); and large for $\mathrm{LDL}_{2}$ (1.220), $\mathrm{LDL}_{3-7}$ (0.819), and mean LDL particle (-1.086).

Table 5. Lipoprotein subfractions ( $\mathrm{mmol} / \mathrm{L})$ and LDL particle size $(\mathrm{nm})$ of the subjects before and after apricot seeds consumption.

\begin{tabular}{lcccccc}
\hline \multirow{2}{*}{ Parameter } & \multicolumn{2}{c}{ NTC $(\boldsymbol{n}=\mathbf{2 1})$} & \multicolumn{3}{c}{ ETC $(\boldsymbol{n}=\mathbf{1 3})$} \\
& Day 0 & Day $\mathbf{4 2}$ & $\boldsymbol{p}$-Value & Day 0 & Day 42 & $p$-Value \\
\hline VLDL & $0.81 \pm 0.14$ & $0.87 \pm 0.20$ & $>0.05$ & $1.14 \pm 0.19$ & $1.06 \pm 0.15$ & $>0.05$ \\
IDL-A & $0.57 \pm 0.14$ & $0.62 \pm 0.14$ & $>0.05$ & $0.65 \pm 0.26$ & $0.76 \pm 0.21$ & $>0.05$ \\
IDL-B & $0.31 \pm 0.07$ & $0.28 \pm 0.08$ & 0.0049 & $0.45 \pm 0.16$ & $0.46 \pm 0.16$ & $>0.05$ \\
IDL-C & $0.43 \pm 0.08$ & $0.46 \pm 0.09$ & $>0.05$ & $0.62 \pm 0.06$ & $0.64 \pm 0.18$ & $>0.05$ \\
LDL & $0.77 \pm 0.18$ & $0.72 \pm 0.17$ & $>0.05$ & $1.16 \pm 0.22$ & $1.00 \pm 0.21$ & 0.0035 \\
LDL $_{2}$ & $0.15(0.07-0.21)$ & $0.08(0.05-0.15)$ & 0.0393 & $0.52(0.30-0.63)$ & $0.18(0.13-0.38)$ & 0.0002 \\
LDL $3-7$ & $0(0-0)$ & $0(0-0)$ & $>0.05$ & $0(0-0.05)$ & $0(0-0)$ & 0.0431 \\
HDL & $1.15 \pm 0.20$ & $1.12 \pm 0.22$ & $>0.05$ & $1.33 \pm 0.26$ & $1.26 \pm 0.30$ & $>0.05$ \\
Total LDL & $2.29 \pm 0.38$ & $2.25 \pm 0.44$ & $>0.05$ & $3.39 \pm 0.43$ & $3.09 \pm 0.54$ & 0.0019 \\
Mean LDL & $27.39 \pm 0.27$ & $27.48 \pm 0.24$ & 0.0326 & $27.24 \pm 0.21$ & $27.43 \pm 0.14$ & 0.0015 \\
particle size & & & & &
\end{tabular}

Abbreviations: NTC, normal total cholesterol; ETC, elevated total cholesterol; VLDL, very low-density lipoproteins; IDL, intermediate-density lipoproteins; LDL, low-density lipoproteins; HDL, high-density lipoproteins. Data are expressed as mean \pm standard deviation (SD) or median (interquartile range). Paired $t$-test for normally distributed variables and Wilcoxon Signed-Ranks Test for not normally distributed variables.

In this study, we found some atherogenic LDL subfractions ( $\mathrm{LDL}_{3-7}$ ) in three volunteers from the NTC and five volunteers from the ETC group. At the end of the study, we found a manifestation of atherogenic subtractions only in one man from the NTC group and in one man from the ETC group. After the six-week bitter apricot seeds consumption, the 
number of subjects with fractions $\mathrm{LDL}_{3-7}$ decreased in both group (by $9.53 \%$ in NTC group and by $30.77 \%$ in ETC group). We found intermediate-pattern AB only in two volunteers in the NTC group, but after a six-week intervention, only one participant was classified as intermediate-pattern $(\mathrm{AB})$, while all others were evaluated as a non-atherogenic lipoprotein profile type (A). Figure 1 shows a representative lipoprotein profile of proband from NTC group in response to the intervention.

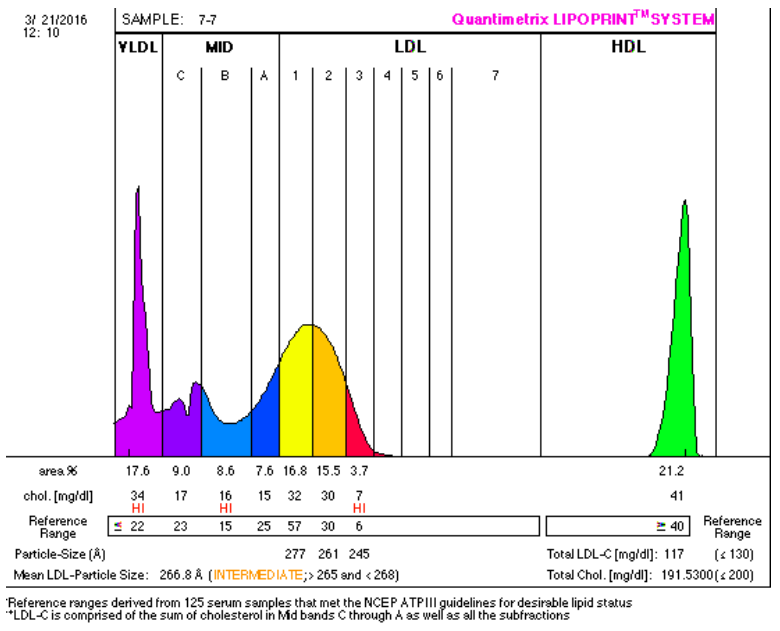

(a)

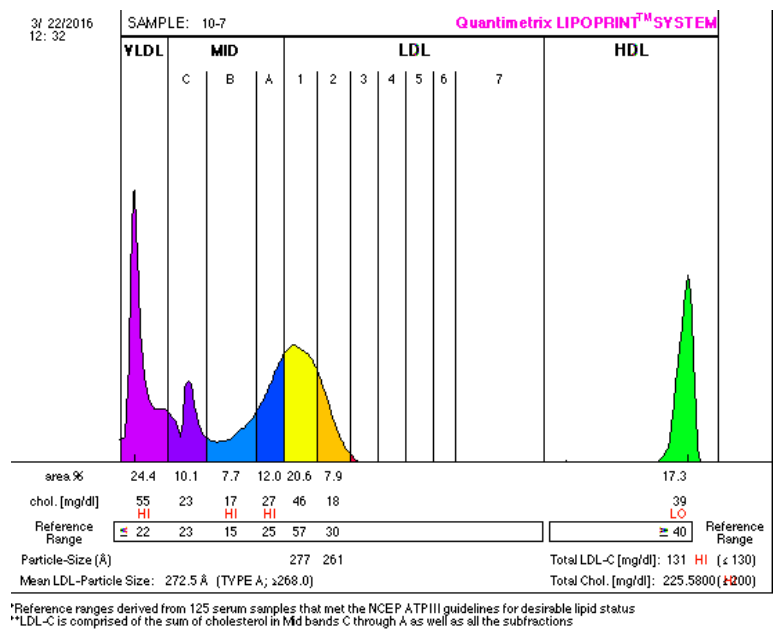

(b)

Figure 1. A representative lipoprotein profile of one proband from NTC group at baseline (a) and after consumption (b) of bitter apricot seeds. Atherogenic subfractions LDL $_{3-7}$ are in red; the large-less atherogenic subfractions $\mathrm{LDL}_{1}$ and $\mathrm{LDL}_{2}$ are in yellow.

\subsection{Effect of Bitter Apricot Seeds Consumption on High-Sensitivity CRP, CK, and Liver Enzymes}

High-sensitivity CRP, CK, and the enzyme activities of AST, ALT, ALP, and GGT during consumption of apricot seeds are shown in Table 6. After the intervention, nonsignificant decrease of hs-CRP and non-significant increase of CK was recorded in both groups $(p>0.05)$. Serum AST activity decreased significantly $(p<0.01)$, and activity of GGT increased significantly $(p<0.05)$ in NTC group. At the start of the study, three participants in this group had GGT values lower than their physiological values, but after 42 days, they had GGT in the normal range. The activities of liver enzymes did not change significantly $(p>0.05)$ after 42 days of bitter apricot seeds consumption in ETC group. In this study, the average values of the activity of liver enzymes in all the participants were in the range of physiological values. The Cohen's $d$ effect sizes of high-sensitivity CRP, CK, and liver enzymes for the change from baseline to week six was $<0.1$ for both groups.

Table 6. High-sensitivity CRP, CK, and liver enzymes of the subjects before and after apricot seeds consumption.

\begin{tabular}{lcccccc}
\hline \multirow{2}{*}{ Parameter } & \multicolumn{2}{c}{ NTC $(\boldsymbol{n}=\mathbf{2 1})$} & \multicolumn{2}{c}{ ETC $(\boldsymbol{n}=\mathbf{1 3})$} \\
& Day 0 & Day 42 & $p$-Value & Day 0 & Day 42 & $p$-Value \\
\hline hs-CRP $(\mathrm{mg} / \mathrm{L})$ & $0.26(0.14-0.61)$ & $0.50(0.21-0.98)$ & $>0.05$ & $1.46(0.62-3.19)$ & $1.28(0.62-3.24)$ & $>0.05$ \\
CK $(\mathrm{mg} / \mathrm{L})$ & $1.93 \pm 1.03$ & $2.09 \pm 1.19$ & $>0.05$ & $1.76 \pm 0.96$ & $1.94 \pm 0.89$ & $>0.05$ \\
ALP $(\mu \mathrm{kat} / \mathrm{L})$ & $0.80 \pm 0.31$ & $0.82 \pm 0.29$ & $>0.05$ & $0.97 \pm 0.16$ & $1.01 \pm 0.20$ & $>0.05$ \\
AST $(\mu \mathrm{kat} / \mathrm{L})$ & $0.36 \pm 0.11$ & $0.31 \pm 0.08$ & 0.0075 & $0.39 \pm 0.09$ & $0.38 \pm 0.11$ & $>0.05$ \\
ALT $(\mu \mathrm{kat} / \mathrm{L})$ & $0.35 \pm 0.16$ & $0.33 \pm 0.1$ & $>0.05$ & $0.45 \pm 0.29$ & $0.47 \pm 0.21$ & $>0.05$ \\
GGT $(\mu \mathrm{kat} / \mathrm{L})$ & $0.27 \pm 0.20$ & $0.35 \pm 0.14$ & 0.0370 & $0.45 \pm 0.30$ & $0.46 \pm 0.27$ & $>0.05$ \\
\hline
\end{tabular}

Abbreviations: NTC, normal total cholesterol; ETC, elevated total cholesterol; hs-CRP, high-sensitivity C-reactive protein; CK, creatine kinase; ALP, alkaline phosphatase; AST, aspartate aminotransferase; ALT, alanine aminotransferase; GGT, gamma glutamyl transferase. Data are expressed as mean \pm standard deviation (SD) or median (interquartile range). Paired $t$-test for normally distributed variables and Wilcoxon Signed-Ranks Test for not normally distributed variables. 


\subsection{Comparison of Monitored Parameters after Nutrition Intervention Adjusted for Body Mass Index (BMI) and Sex}

The covariance analysis (ANCOVA) showed that the differences observed in the monitored variables were not affected by body mass index and only to a small extent by sex, which may also be related to the gender imbalance of the NTC group, the predominance of women compared to men $(66.7 \%$ vs. $33.3 \%)$, and the possible impact of age. The mean age in this group was $37.50 \pm 9.13$ years for women and $33.14 \pm 3.18$ years for men. There were no significant interactions for changes in all parameters adjusted for BMI in ETC group. The effect of sex in the ETC group was manifested only in the HDL-C, which was expected, as women have physiologically higher HDL compared to men (Table 7).

Table 7. Changes of monitored parameters after nutrition intervention adjusted for body mass index (BMI) and sex.

\begin{tabular}{|c|c|c|c|c|c|c|}
\hline \multirow{2}{*}{ Parameter } & \multicolumn{3}{|c|}{$\operatorname{NTC}(n=21)$} & \multicolumn{3}{|c|}{$\operatorname{ETC}(n=13)$} \\
\hline & Difference $^{a}$ & $p$-Value ${ }^{\mathrm{b}}$ & $p$-Value ${ }^{\mathrm{c}}$ & Difference $^{a}$ & $p$-Value ${ }^{b}$ & $p$-Value ${ }^{\mathrm{c}}$ \\
\hline $\mathrm{T}-\mathrm{C}(\mathrm{mmol} / \mathrm{L})$ & $0.00 \pm 0.44$ & 0.0290 & $>0.05$ & $0.35 \pm 0.47$ & $>0.05$ & $>0.05$ \\
\hline LDL-C (mmol/L) & $-0.01 \pm 0.40$ & 0.013 & $>0.05$ & $0.38 \pm 0.39$ & $>0.05$ & $>0.05$ \\
\hline HDL-C (mmol/L) & $0.02 \pm 0.13$ & $>0.05$ & $>0.05$ & $-0.04 \pm 0.19$ & 0.014 & $>0.05$ \\
\hline $\mathrm{TG}(\mathrm{mmol} / \mathrm{L})$ & $-0.05 \pm 0.22$ & $>0.05$ & $>0.05$ & $0.04 \pm 0.42$ & $>0.05$ & $>0.05$ \\
\hline VLDL (mmol/L) & $-0.06 \pm 0.18$ & 0.0087 & 0.0100 & $0.08 \pm 0.19$ & $>0.05$ & $>0.05$ \\
\hline IDL-C (mmol/L) & $-0.04 \pm 0.11$ & 0.0078 & $>0.05$ & $-0.03 \pm 0.16$ & $>0.05$ & $>0.05$ \\
\hline IDL-B (mmol/L) & $0.03 \pm 0.04$ & $>0.05$ & $>0.05$ & $-0.01 \pm 0.08$ & $>0.05$ & $>0.05$ \\
\hline IDL-A (mmol/L) & $-0.05 \pm 0.13$ & 0.0355 & $>0.05$ & $-0.11 \pm 0.22$ & $>0.05$ & $>0.05$ \\
\hline $\mathrm{LDL}_{1}(\mathrm{mmol} / \mathrm{L})$ & $0.05 \pm 0.16$ & $>0.05$ & $>0.05$ & $0.16 \pm 0.16$ & $>0.05$ & $>0.05$ \\
\hline $\mathrm{LDL}_{2}(\mathrm{mmol} / \mathrm{L})$ & $0.06 \pm 0.13$ & $>0.05$ & $>0.05$ & $0.28 \pm 0.20$ & $>0.05$ & $>0.05$ \\
\hline $\mathrm{LDL}_{3-7}(\mathrm{mmol} / \mathrm{L})$ & $0.00 \pm 0.05$ & $>0.05$ & $>0.05$ & $0.02 \pm 0.03$ & $>0.05$ & $>0.05$ \\
\hline LDL particle size $(\mathrm{nm})$ & $-0.86 \pm 1.71$ & $>0.05$ & $>0.05$ & $-1.92 \pm 1.71$ & $>0.05$ & $>0.05$ \\
\hline $\mathrm{GLU}(\mathrm{mmol} / \mathrm{L})$ & $-0.17 \pm 0.50$ & 0.0243 & $>0.05$ & $-0.12 \pm 0.43$ & $>0.05$ & $>0.05$ \\
\hline AST $(\mu \mathrm{kat} / \mathrm{L})$ & $0.06 \pm 0.09$ & $>0.05$ & $>0.05$ & $0.01 \pm 0.08$ & $>0.05$ & $>0.05$ \\
\hline $\operatorname{ALT}(\mu \mathrm{kat} / \mathrm{L})$ & $0.02 \pm 0.10$ & $>0.05$ & $>0.05$ & $-0.02 \pm 0.17$ & $>0.05$ & $>0.05$ \\
\hline $\operatorname{ALP}(\mu \mathrm{kat} / \mathrm{L})$ & $-0.03 \pm 0.09$ & $>0.05$ & $>0.05$ & $-0.05 \pm 0.08$ & $>0.05$ & $>0.05$ \\
\hline GGT $(\mu \mathrm{kat} / \mathrm{L}))$ & $-0.08 \pm 0.16$ & $>0.05$ & 0.0427 & $-0.01 \pm 0.08$ & $>0.05$ & $>0.05$ \\
\hline $\mathrm{CK}(\mathrm{mg} / \mathrm{L})$ & $-0.16 \pm 0.42$ & $>0.05$ & $>0.05$ & $-0.18 \pm 0.79$ & $>0.05$ & $>0.05$ \\
\hline$h \mathrm{~s}-\mathrm{CRP}(\mathrm{mg} / \mathrm{L})$ & $-0.04 \pm 1.01$ & $>0.05$ & $>0.05$ & $0.07 \pm 0.76$ & $>0.05$ & $>0.05$ \\
\hline
\end{tabular}

Abbreviations: NTC, normal total cholesterol; ETC, elevated total cholesterol; BMI, body mass index; T-C, total cholesterol; HDL-C, high-density cholesterol; LDL-C, low-density cholesterol; TG, triglycerides; VLDL, very low-density lipoproteins; IDL, intermediate-density lipoproteins; GLU, glucose; AST, aspartate aminotransferase ALT, alanine aminotransferase; ALP, alkaline phosphatase; GGT, gamma glutamyl transferase; CK, creatine kinase; hs-CRP, high-sensitivity C-reactive protein. Data are expressed as mean \pm standard deviation (SD); ${ }^{a}$ difference between pre- and post- intervention. All $p$-values ${ }^{b, c}$ are obtained from the ANCOVA analysis with adjustment for baseline values (covariates ${ }^{\mathrm{b}}$ sex, $^{\mathrm{c}} \mathrm{BMI}$ ).

\section{Discussion}

The aim of this study was to evaluate the effects of short-term consumption of bitter apricot seeds phytonutrients on cardiovascular risk factors with a special focus on LDL cholesterol subfractions of adults with elevated cholesterol levels.

Dietary recommendations for the prevention of chronic diseases have now shifted towards diets high in plant foods and low in animal foods [61-63] not only because of low saturated fat and cholesterol but also because of the significant amounts of micronutrients and bioactive compounds $[64,65]$. This dietary pattern has been associated with lower risk of CVD [66-69] and is widely recommended for heart health [70].

In recent years, seeds and nuts have received growing attention due to high nutraceutical and therapeutic value of their bioactive components [71-74]. Some of the reported health benefits derived from nut and seed consumption are control of body weight and blood pressure, reduction of coronary heart disease, and reduction of levels of blood cholesterol and triacylglycerols $[75,76]$. There is substantial evidence that increased consumption of seeds is associated with lower risk of CVD and T2DM or a significant reduction in CVD 
risk factors, such as serum cholesterol or blood pressure [77]. In addition, nuts and edible seeds provide antioxidant, anti-microbial, anti-inflammatory, anti-mutagenic, anti-cancer, anti-diabetic, and glucoregulatory properties [75,78]. Apricot seeds and almond oil are rich in mono- and polyunsaturated fatty acids [79]. A meta-analysis of clinical trials concluded that nut intake led to a significant beneficial effect on triglycerides, total cholesterol, LDL, and Apo B [80]. In an earlier study, almonds in the daily diet reduced LDL-C by as much as $9.4 \%$, reduced the LDL:HDL ratio by $12.0 \%$, and increased HDL-C by $4.6 \%$ [81]. Zibaeenezhad et al. [82] found that supplementation of Amygdalus scoparia kernel oil had a positive effect on lowering serum triglycerides in patients with dyslipidemia without a significant effect on serum cholesterol levels. In our experiment, we observed a positive effect on both triglycerides and total cholesterol levels in the ETC group.

Our and previous studies indicate a high concentration of important bioactive substances with potential health benefits. The main bioactive components of apricot oil are fatty acids, tocopherols, and phenolic compounds [83-85]. Apricot kernel oil contains some biologically active substances, such as $\beta$-carotene $(61.05 \mathrm{mg} / \mathrm{g})$, tocopherols $(50.76 \mathrm{mg} / 100 \mathrm{~g})$, phenolic compounds, campesterol (11.8 mg/100 g), stigmasterol (9.8 mg/100 g), sitosterol (177.0 mg/100 g), and provitamin A [86,87]. Seed oils from Prunus species contain high amounts of recommended monounsaturated oleic acid (60-70.9\%), moderate content of linoleic acid (20-30\%), and low amounts of saturated fatty acids [86-88], which is also in line with our results. Polyunsaturated and monosaturated fatty acids are important for normal growth and development and are suggested to play an important role in modulation of cardiovascular inflammatory diseases and cancer [89]. Amygdalin, a bioactive component of bitter apricot seeds, has controversial functions in cancer therapy [90], Jiagang et al. [91] first examined its therapeutic effect in atherosclerosis. They found decreased TG and T-C levels $(p<0.05)$ in mice treated by amygdalin $(1 \mathrm{mg} / \mathrm{kg})$. Meanwhile, amygdalin treatment also decreased the LDL-C levels $(p<0.05)$. However, the treatment of amygdalin did not induce any decline in HDL-C levels $(p>0.05)$. Of the phenolic compounds in tested bitter apricot seeds, we mainly determined gallic acid $(30.1 \mathrm{mg} / \mathrm{g})$ and rutin $(11.3 \mathrm{mg} / \mathrm{g})$. Gallic acid (GA) is one of the most important herbal products that has beneficial effects on CVD [92-94]. A small amount of GA (in the range of daily consumption in central Europe) prevents oxidative DNA damage and reduces markers that reflect inflammation and increased risks of cancer and CVD [95]. Flavonoids, of which rutin is a typical representative, serve a positive role in the treatment of cardiovascular and cerebrovascular diseases [96]. Rutin has a variety of pharmacological actions, including radical reactivity and protective activity against lipid peroxidation, viruses, and acute pancreatitis; thus, it may be used as a treatment for many diseases. Rutin significantly reduced the levels of total cholesterol and LDL-C and also markedly decreased liver enzymes and weight in animals with a high-cholesterol diet [97].

Despite their relatively high energy density, intake of nuts and seeds was actually associated with less weight gain, lower risk of obesity, and lower risk of moderate weight gain in prospective studies [98-100]. When comparing changes in body composition, we found a significant decrease in BW, BFM, and BMI in the NTC group, but we observed a significant increase in BW, VFA, and BMI in the ETC group. Hypercholesterolemia is the main risk factor of cardiovascular diseases, such as atherosclerosis, myocardial infarction, stroke, and cerebrovascular diseases. Elevated LDL-C and decreased HDL-C are important risk factors for cardiovascular diseases, particularly for coronary artery disease [101,102]. Despite the causal role of LDL cholesterol in development of atherosclerosis, previous studies have indicated that the association of elevated total cholesterol with myocardial infarction and ischemic heart disease varies greatly with age, with the association being much stronger in younger than older individuals [103-106]. Age is an uncontrollable risk factor for elevated cholesterol level, which is consistent with our results; NTC subjects were significantly younger in comparison to ETC subjects.

In our previous studies, consumption of bitter apricot seeds also caused significant reductions $(p<0.05)$ in T-C and LDL-C levels in healthy volunteers [57] and also in women of 
reproductive age [107]. In the present study, the blood serum levels of T-C, LDL-C, HDL-C, and TG did not change significantly $(p>0.05)$ after 42 days of bitter apricot seeds consumption in NTC group; however, there were significant reduction in the total cholesterol $(p<0.05)$ and LDL-cholesterol $(p<0.01)$ in ETC group after 42 days of apricot seeds consumption. A 5\% reduction in LDL-cholesterol is significant, as it could reduce risk of CHD from $5 \%$ to $15 \%$; every $1 \%$ reduction in LDL-C is associated with a decreased risk for CHD of $1 \%$ to $3 \%$ [108-111]. A high concentration of plasma triglycerides has been associated with cardiovascular disease risk in humans for several decades [112]. In our study, triglycerides concentrations was not significantly $(p>0.05)$ changed by six weeks of apricot seed consumption in both groups. LDL-C is accepted as a causal risk factor for development of myocardial infarction and atherosclerotic cardiovascular disease [113]. Evidence suggests that lipoprotein particle size and the distribution of cholesterol in LDL and HDL subfractions may be better predictors of CVD than traditional lipid profiles [114-117]. Although nutraceuticals and herbal medicine have been previously studied as a non-pharmacological management of dyslipidemia [118-122], greater clarity on the effects of these bioactive natural compounds in improving sdLDL for the reduction in the relative risk of CVD is needed. To date, there is no study that has investigated the effect of phytonutrients of bitter apricot seeds on sdLDL levels. There are evidences that the small LDL number was significantly decreased in the pistachio-supplemented diet $[37,123]$, hazelnut-enriched diet [124], and walnuts diet [125]. After 42 days of consumption of apricot seeds, there were significant differences in the IDL-B $(p<0.01)$ and LDL2 $(p<0.05)$ in NTC group. The athero-protective role of $\mathrm{LDL}_{1}$ subfraction has been demonstrated [126,127], but the role of $\mathrm{LDL}_{2}$ subfraction has not been determined yet [127]. It is assumed that, in the class of LDL lipoproteins, the subfractions $\mathrm{LDL}_{1}$ and $\mathrm{LDL}_{2}$ are the least atherogenic [23]. In our study, the $\mathrm{LDL}_{1}$ and $\mathrm{LDL}_{2}$ subfractions progressively decreased during the intervention $(p<0.01)$ in ETC group, but there was always significant decrease in the atherogenic $\operatorname{LDL}_{3-7}(p<0.05)$. Zitnanova et al. [126] demonstrated the protective role of IDL-A in the atherogenic process; in this study, IDL-A increase was insignificant $(p>0.05)$ in both groups.

The present work studied adults with normal (NTC) or elevated cholesterol levels (ETC), and some atherogenic LDL subfractions $\left(\mathrm{LDL}_{3-7}\right)$ at the baseline were found in three volunteers from the NTC and five volunteers from the ETC group. According to Oravec et al. [127] the atherogenic lipoprotein profile might be present in about $6 \%$ of normolipidemic, young healthy individuals. At the end of the study, we found the LDL $_{3-7}$ fraction only in one man from the NTC group and in one man from the ETC group. Nonetheless, the main conclusion of this study was that after the six-week bitter apricot seeds consumption, the number of subjects with fraction LDL $_{3-7}$ decreased in both group (by $9.53 \%$ in NTC group and by $30.77 \%$ in ETC group). Furthermore, apricot seeds consumption was associated with a significant increase in the mean LDL particle size, especially in ETC group $(p<0.01)$ with large Cohen's $d$ effect sizes from baseline to week six. It is interesting to note that we found intermediate-pattern AB only in two volunteers in the NTC group, but after a six-week intervention, only one participant was classified as intermediate-pattern $(\mathrm{AB})$, while all others were evaluated as a non-atherogenic lipoprotein profile type (A). Previous studies have shown that particle size represents a threefold increase in cardiovascular risk, independent of other lipid parameters [117,128].

Apricot seeds are used to enrich noodles [129], are added to bakery products as whole seeds or are ground, and are also consumed as an appetizer [130]. Apricot seeds can become part of the normal daily diet, such as nuts, flax seeds, and others, to increase nutritional value, but their consumption is limited because of their content of amygdalin.

This study had certain limitations. The major limitation of our study is the small number of participants, which could decrease the statistical power to detect differences during the follow-up. The next limitation of our study is the age-unbalanced groups of participants; subjects in the group with hypercholesterolemia were older in comparison to subjects with normal levels of total cholesterol. Whole-body cholesterol metabolism is maintained by a highly coordinated balancing act between cholesterol ingestion, synthesis, 
absorption, and excretion, and ageing interacts with these processes. Another limitation is the short duration of this intervention study. Further studies with a larger sample size, longer duration, and age-balanced participants are needed to further investigate the extent to which apricot seeds may affect the lipid profile.

\section{Conclusions}

In recent years, growing scientific evidence has demonstrated specific biological activities of phytonutrients or phytochemicals, which can have a significant impact on the course of some diseases, particularly cardiovascular disease. This study was designed to reveal whether short-term consumption of bitter apricot seeds has any effect on lipid profile and LDL lipoprotein subfractions in adults with elevated total cholesterol.

The atherogenic lipoprotein profile might be present in about $6 \%$ of normolipidemic, young healthy individuals. Nonetheless, the main conclusion of this study was that after the six-week bitter apricot seeds consumption, the number of subjects with atherogenic fraction $\mathrm{LDL}_{3-7}$ decreased in both groups. The results of the present study support the hypothesis that daily consumption of bitter apricot seeds for 42 days positively modified the lipoprotein profile in the group with elevated total cholesterol and had no negative effect on lipid metabolism in the group of healthy probands.

Future studies to optimize the benefit of regular consumption of bitter apricot seeds and to determine the clinical relevance of metabolic change are justified as outlined in this study. Coupled with changes in traditional lipoprotein measurements, these improvements represent a favorable shift in the atherogenic phenotype and suggest that lifestyle interventions can improve early markers of atherosclerosis.

Author Contributions: Conceptualization, J.K. and M.S.; methodology, J.K. and A.K. (Anna Kolesárová); software, J.M. and M.G.; validation, M.S. and M.G.; formal analysis, P.L. and P.C.; investigation, A.K. (Anna Kolesárová) and A.K. (Anton Kováčik); resources, M.G. and P.L.; data curation, J.M. and P.C.; writing-original draft preparation, J.K. and M.S.; writing — review and editing, J.K. and P.C.; visualization, A.K. (Anna Kolesárová) and A.K. (Anton Kováčik); supervision, A.K. (Adriana Kolesárová); project administration, J.K.; funding acquisition, A.K. (Adriana Kolesárová). All authors have read and agreed to the published version of the manuscript.

Funding: This work was supported by the Ministry of Education, Science, Research, and Sport of the Slovak Republic projects APVV-18-0312, VEGA 1/0 266/20, the Operational Program Integrated Infrastructure within the project: Demand-driven research for the sustainable and innovative food, Drive4SIFood 313011V336, cofinanced by the European Regional Development Fund.

Institutional Review Board Statement: This study was conducted according to the guidelines of the Declaration of Helsinki and approved by the Ethics Committee at the Specialized Hospital S $t$. Zoerardus Zobor, n. o. Nitra, Slovak Republic (protocol number 030809/2015).

Informed Consent Statement: A written informed consent was obtained from all participants involved in the study.

Data Availability Statement: All datasets related to the results of this study are available from the primary author on request.

Acknowledgments: The authors would like to thank all participants who participated in this study.

Conflicts of Interest: The authors declare no conflict of interest.

\section{References}

1. Brandhorst, S.; Longo, V.D. Dietary Restrictions and Nutrition in the Prevention and Treatment of Cardiovascular Disease. Circ. Res. 2019, 124, 952-965. [CrossRef] [PubMed]

2. Mahmoudi, M. The Pathogenesis of Atherosclerosis. Medicine 2018, 46, 505-508. [CrossRef]

3. Kaplan, H.; Thompson, R.C.; Trumble, B.C.; Wann, L.S.; Allam, A.H.; Beheim, B.; Frohlich, B.; Sutherland, M.L.; Sutherland, J.D.; Stieglitz, J.; et al. Coronary Atherosclerosis in Indigenous South American Tsimane: A Cross-Sectional Cohort Study. Lancet 2017, 389, 1730-1739. [CrossRef] 
4. Gimbrone, M.A.; Topper, J.N.; Nagel, T.; Anderson, K.R.; Garcia-Cardeña, G. Endothelial Dysfunction, Hemodynamic Forces, and Atherogenesis. Ann. N. Y. Acad. Sci. 2000, 902, 230-239; discussion 239-240. [CrossRef]

5. Kuk, M.; Ward, N.C.; Dwivedi, G. Extrinsic and Intrinsic Responses in the Development and Progression of Atherosclerosis. Heart Lung Circ. 2021, 30, 807-816. [CrossRef] [PubMed]

6. Brown, R.A.; Shantsila, E.; Varma, C.; Lip, G.Y. Current Understanding of Atherogenesis. Am. J. Med. 2017, 130, 268-282. [CrossRef]

7. Wang, T.; Butany, J. Pathogenesis of Atherosclerosis. Diagn. Histopathol. 2017, 23, 473-478. [CrossRef]

8. Tabas, I.; Lichtman, A.H. Monocyte-Macrophages and T Cells in Atherosclerosis. Immunity 2017, 47, 621-634. [CrossRef] [PubMed]

9. Mathers, C.D.; Loncar, D. Projections of global mortality and burden of disease from 2002 to 2030. PLoS Med. 2006, 3, e442. [CrossRef] [PubMed]

10. Lyons, J.G.; O’Dea, K.; Walker, K.Z. Evidence for Low High-Density Lipoprotein Cholesterol Levels in Australian Indigenous Peoples: A Systematic Review. BMC Public Health 2014, 14, 545. [CrossRef] [PubMed]

11. Acharjee, S.; Boden, W.E.; Hartigan, P.M.; Teo, K.K.; Maron, D.J.; Sedlis, S.P.; Kostuk, W.; Spertus, J.A.; Dada, M.; Chaitman, B.R.; et al. Low Levels of High-Density Lipoprotein Cholesterol and Increased Risk of Cardiovascular Events in Stable Ischemic Heart Disease Patients: A Post-Hoc Analysis from the COURAGE Trial (Clinical Outcomes Utilizing Revascularization and Aggressive Drug Evaluation). J. Am. Coll. Cardiol. 2013, 62, 1826-1833. [PubMed]

12. Klop, B.; Elte, J.W.F.; Cabezas, M.C. Dyslipidemia in Obesity: Mechanisms and Potential Targets. Nutrients 2013, 5, 1218-1240. [CrossRef] [PubMed]

13. Barter, P.; Gotto, A.M.; LaRosa, J.C.; Maroni, J.; Szarek, M.; Grundy, S.M.; Kastelein, J.J.P.; Bittner, V.; Fruchart, J.-C.; Treating to New Targets Investigators. HDL Cholesterol, Very Low Levels of LDL Cholesterol, and Cardiovascular Events. N. Engl. J. Med. 2007, 357, 1301-1310. [CrossRef] [PubMed]

14. Ference, B.A.; Ginsberg, H.N.; Graham, I.; Ray, K.K.; Packard, C.J.; Bruckert, E.; Hegele, R.A.; Krauss, R.M.; Raal, F.J.; Schunkert, H.; et al. Low-Density Lipoproteins Cause Atherosclerotic Cardiovascular Disease. 1. Evidence from Genetic, Epidemiologic, and Clinical Studies. A Consensus Statement from the European Atherosclerosis Society Consensus Panel. Eur. Heart J. 2017, 38, 2459-2472. [CrossRef] [PubMed]

15. Jacobson, T.A.; Maki, K.C.; Orringer, C.E.; Jones, P.H.; Kris-Etherton, P.; Sikand, G.; La Forge, R.; Daniels, S.R.; Wilson, D.P.; Morris, P.B.; et al. National Lipid Association Recommendations for Patient-Centered Management of Dyslipidemia: Part 2. J. Clin. Lipidol. 2015, 9 (Suppl. 6), S1-S122.e1. [CrossRef] [PubMed]

16. Boekholdt, S.M.; Arsenault, B.J.; Mora, S.; Pedersen, T.R.; LaRosa, J.C.; Nestel, P.J.; Simes, R.J.; Durrington, P.; Hitman, G.A.; Welch, K.M.A.; et al. Association of LDL Cholesterol, Non-HDL Cholesterol, and Apolipoprotein B Levels with Risk of Cardiovascular Events among Patients Treated with Statins: A Meta-Analysis. JAMA 2012, 307, 1302-1309. [CrossRef]

17. Austin, M.A.; King, M.C.; Vranizan, K.M. Atherogenic lipoprotein phenotype. A proposed genetic marker for coronary heart disease risk. Circulation 1990, 82, 495-506. [CrossRef]

18. Van, J.; Pan, J.; Charles, M.A.; Krauss, R.; Wong, N.; Wu, X. Atherogenic Lipid Phenotype in a General Group of Subjects. Arch Pathol. Lab. Med. 2007, 131, 1679-1685. [CrossRef]

19. Superko, H.R.; Pendyala, L.; Williams, P.T.; Momary, K.M.; King, S.B.; Garrett, B.C. High-Density Lipoprotein Subclasses and Their Relationship to Cardiovascular Disease. J. Clin. Lipidol. 2012, 6, 496-523. [CrossRef]

20. Rosenson, R.S.; Brewer, H.B.; Chapman, M.J.; Fazio, S.; Hussain, M.M.; Kontush, A.; Krauss, R.M.; Otvos, J.D.; Remaley, A.T.; Schaefer, E.J. HDL Measures, Particle Heterogeneity, Proposed Nomenclature, and Relation to Atherosclerotic Cardiovascular Events. Clin. Chem. 2011, 57, 392-410. [CrossRef]

21. Vandermeersch, A.; Ameye, S.; Puype, D.; Petitjean, D.; De Buyzere, M.; Langlois, M.R. Estimation of the Low-Density Lipoprotein (LDL) Subclass Phenotype Using a Direct, Automated Assay of Small Dense LDL-Cholesterol without Sample Pretreatment. Clin. Chim. Acta 2010, 411, 1361-1366. [CrossRef] [PubMed]

22. Ivanova, E.A.; Myasoedova, V.A.; Melnichenko, A.A.; Grechko, A.V.; Orekhov, A.N. Small Dense Low-Density Lipoprotein as Biomarker for Atherosclerotic Diseases. Oxid. Med. Cell. Longev. 2017, 2017, 1273042. [CrossRef] [PubMed]

23. Oravec, S.; Dostal, E.; Dukát, A.; Gavorník, P.; Kucera, M.; Gruber, K. HDL Subfractions Analysis: A New Laboratory Diagnostic Assay for Patients with Cardiovascular Diseases and Dyslipoproteinemia. Neuro Endocrinol. Lett. 2011, 32, 502-509. [PubMed]

24. Kwon, S.W.; Yoon, S.-J.; Kang, T.S.; Kwon, H.M.; Kim, J.-H.; Rhee, J.; Lee, S.-J.; Park, J.-K.; Lim, J.Y.; Yoon, Y.W.; et al. Significance of Small Dense Low-Density Lipoprotein as a Risk Factor for Coronary Artery Disease and Acute Coronary Syndrome. Yonsei Med. J. 2006, 47, 405-414. [CrossRef]

25. Austin, M.A.; Breslow, J.L.; Hennekens, C.H.; Buring, J.E.; Willett, W.C.; Krauss, R.M. Low-Density Lipoprotein Subclass Patterns and Risk of Myocardial Infarction. JAMA 1988, 260, 1917-1921. [CrossRef] [PubMed]

26. Yee, M.S.; Pavitt, D.V.; Tan, T.; Venkatesan, S.; Godsland, I.F.; Richmond, W.; Johnston, D.G. Lipoprotein Separation in a Novel Iodixanol Density Gradient, for Composition, Density, and Phenotype Analysis. J. Lipid. Res. 2008, 49, 1364-1371. [CrossRef] [PubMed]

27. Witte, D.R.; Taskinen, M.R.; Perttunen-Nio, H.; Van Tol, A.; Livingstone, S.; Colhoun, H.M. Study of Agreement between LDL Size as Measured by Nuclear Magnetic Resonance and Gradient Gel Electrophoresis. J. Lipid. Res. 2004, 45, 1069-1076. [CrossRef] [PubMed] 
28. Calderon-Santiago, M.; Priego-Capote, F.; Galache-Osuna, J.G.; de Castro, M.L. Method based on GC-MS to study the influence of tricarboxylic acid cycle metabolites on cardiovascular risk factors. J. Pharm. Biomed. Anal. 2012, 74, 178-185. [CrossRef] [PubMed]

29. Kanter, M.M.; Kris-Etherton, P.M.; Fernandez, M.L.; Vickers, K.C.; Katz, D.L. Exploring the factors that affect blood cholesterol and heart disease risk: Is dietary cholesterol as bad for you as history leads us to believe? Adv. Nutr. 2012, 3, 711-717. [CrossRef]

30. Maugeri, A.; Vinciguerra, M. The Effects of Meal Timing and Frequency, Caloric Restriction, and Fasting on Cardiovascular Health: An Overview. J. Lipid Atheroscler. 2020, 9, 140-152. [CrossRef]

31. Siriwardhana, N.; Kalupahana, N.S.; Cekanova, M.; LeMieux, M.; Greer, B.; Moustaid-Moussa, N. Modulation of Adipose Tissue Inflammation by Bioactive Food Compounds. J. Nutr. Biochem. 2013, 24, 613-623. [CrossRef] [PubMed]

32. Hassimotto, N.M.A.; Genovese, M.I.; Lajolo, F.M. Antioxidant Capacity of Brazilian Fruit, Vegetables and Commercially-Frozen Fruit Pulps. J. Food Compos. Anal. 2009, 22, 394-396. [CrossRef]

33. Carbonell-Capella, J.M.; Buniowska, M.; Barba, F.J.; Esteve, M.J.; Frígola, A. Analytical Methods for Determining Bioavailability and Bioaccessibility of Bioactive Compounds from Fruits and Vegetables: A Review. Compr. Rev. Food Sci. Food Saf. 2014, 13, 155-171. [CrossRef]

34. Prakash, D.; Gupta, K.R. The Antioxidant Phytochemicals of Nutraceutical Importance. Open Nutraceuticals J. 2009, 2, 20-35. [CrossRef]

35. Marcus, J.B. Chapter 2-Nutritional and Physical Concerns in Aging; Jacqueline, B., Ed.; Marcus, Aging, Nutrition and Taste; Academic Press: Cambridge, MA, USA, 2019; pp. 25-63. ISBN 9780128135273.

36. Lee, H.-H.; Ahn, J.-H.; Kwon, A.-R.; Lee, E.S.; Kwak, J.-H.; Min, Y.-H. Chemical Composition and Antimicrobial Activity of the Essential Oil of Apricot Seed. Phytother. Res. 2014, 28, 1867-1872. [CrossRef] [PubMed]

37. Hernandez-Alonso, P.; Salas-Salvado, J.; Baldrich-Mora, M.; Mallol, R.; Correig, X.; Bullo, M. Effect of pistachio consumption on plasma lipoprotein subclasses in pre-diabetic subjects. Nutr. Metab. Cardiovasc. Dis. 2015, 25, 396-402. [CrossRef]

38. Soong, Y.Y.; Barlow, P.J. Antioxidant activity and phenolic content of selected fruit seeds. Food Chem. 2004, 88, 411-417. [CrossRef]

39. Gomez, E.; Burgos, L.; Soriano, C.; Marin, J. Amygdalin content in the seeds of several apricot cultivars. J. Sci. Food Agric. 1993, 77, 184-186. [CrossRef]

40. Chang, H.K.; Yang, H.Y.; Lee, T.H.; Shin, M.C.; Lee, M.H.; Shin, M.S.; Kim, C.J.; Kim, O.J.; Hong, S.P.; Cho, S. Armeniacae Semen Extract Suppresses Lipopolysaccharide-Induced Expressions of Cyclooxygenase [Correction of Cycloosygenase]-2 and Inducible Nitric Oxide Synthase in Mouse BV2 Microglial Cells. Biol. Pharm. Bull. 2005, 28, 449-454. [CrossRef] [PubMed]

41. Badr, J.M.; Tawfik, M.K. Analytical and pharmacological investigation of amygdalin in Prunus armeniaca L. kernels. J. Pharm. Res. 2010, 3, 2134-2137.

42. Lv, L.; Yao, Y.; Zhao, G.; Zhu, G. Rutin Inhibits Coronary Heart Disease through ERK1/2 and Akt Signaling in a Porcine Model. Exp. Ther. Med. 2018, 15, 506-512. [CrossRef]

43. Gupta, S.; Chhajed, M.; Arora, S.; Thakur, G.; Gupta, R. Medicinal Value of Apricot: A Review. Indian J. Pharm. Sci. 2018, 80, 790-794. [CrossRef]

44. Chen, Y.; Ma, J.; Wang, F.; Hu, J.; Cui, A.; Wei, C.; Yang, Q.; Li, F. Amygdalin Induces Apoptosis in Human Cervical Cancer Cell Line HeLa Cells. Immunopharmacol. Immunotoxicol. 2013, 35, 43-51. [CrossRef] [PubMed]

45. Gomaa, E.Z. In Vitro Antioxidant, Antimicrobial, and Antitumor Activities of Bitter Almond and Sweet Apricot (Prunus Armeniaca L.) Kernels. Food Sci. Biotechnol. 2013, 22, 455-463. [CrossRef]

46. Durmaz, G.; Alpaslan, M. Antioxidant Properties of Roasted Apricot (Prunus Armeniaca L.) Kernel. Food Chemistry 2007, 100, 1177-1181. [CrossRef]

47. Ayaz, Z.; Zainab, B.; Khan, S.; Abbasi, A.M.; Elshikh, M.S.; Munir, A.; Al-Ghamdi, A.A.; Alajmi, A.H.; Alsubaie, Q.D.; Mustafa, A.E.-Z.M. In Silico Authentication of Amygdalin as a Potent Anticancer Compound in the Bitter Kernels of Family Rosaceae. Saudi J. Biol. Sci. 2020, 27, 2444-2451. [CrossRef]

48. Aamazadeh, F.; Ostadrahimi, A.; Rahbar Saadat, Y.; Barar, J. Bitter Apricot Ethanolic Extract Induces Apoptosis through Increasing Expression of Bax/Bcl-2 Ratio and Caspase-3 in PANC-1 Pancreatic Cancer Cells. Mol. Biol. Rep. 2020, 47, 1895-1904. [CrossRef] [PubMed]

49. Cassiem, W.; de Kock, M. The Anti-Proliferative Effect of Apricot and Peach Kernel Extracts on Human Colon Cancer Cells in Vitro. BMC Complement Altern. Med. 2019, 19, 32. [CrossRef]

50. Shen, H.-S.; Wen, S.-H. Effect of Early Use of Chinese Herbal Products on Mortality Rate in Patients with Lung Cancer. J. Ethnopharmacol. 2018, 211, 1-8. [CrossRef] [PubMed]

51. Kolesárová, A.; Pivko, J.; Halenár, M.; Zbyňovská, K.; Chrastinová, Ĺ.; Ondruška, L'; Jurčík, R.; Kopčeková, J.; Valuch, J.; Kolesárová, A. Effect of Apricot Seeds on Renal Structure of Rabbits. Potr. S. J. F. Sci. 2017, 11, 309-314. [CrossRef]

52. Tušimová, E.; Kováčik, A.; Halenár, M.; Michalcová, K.; Zbyňovská, K.; Kolesárová, A.; Kopčeková, J.; Valuch, J.; Kolesárová, A. Does Apricot Seeds Consumption Cause Changes in Human Urine? Potr. S. J. F. Sci. 2017, 11, 244-251. [CrossRef]

53. Ramzan, S.; Soelberg, J.; Jäger, A.K.; Cantarero-Arévalo, L. Traditional Medicine among People of Pakistani Descent in the Capital Region of Copenhagen. J. Ethnopharmacol. 2017, 196, 267-280. [CrossRef] [PubMed]

54. Yamshanov, V.A.; Kovan'ko, E.G.; Pustovalov, Y.I. Effects of Amygdaline from Apricot Kernel on Transplanted Tumors in Mice. Bull. Exp. Biol. Med. 2016, 160, 712-714. [CrossRef] [PubMed]

55. Hu, B.; Wang, S.-S.; Du, Q. Traditional Chinese Medicine for Prevention and Treatment of Hepatocarcinoma: From Bench to Bedside. World J. Hepatol. 2015, 7, 1209-1232. [CrossRef] [PubMed] 
56. Korekar, G.; Stobdan, T.; Arora, R.; Yadav, A.; Singh, S.B. Antioxidant Capacity and Phenolics Content of Apricot (Prunus Armeniaca L.) Kernel as a Function of Genotype. Plant Foods Hum. Nutr. 2011, 66, 376-383. [CrossRef]

57. Kopčeková, J.; Kolesárová, A.; Kováčik, A.; Kováčiková, E.; Gažarová, M.; Chlebo, P.; Valuch, J.; Kolesárová, A. Influence of Long-Term Consumption of Bitter Apricot Seeds on Risk Factors for Cardiovascular Diseases. J. Environ. Sci. Health B 2018, 53, 298-303. [CrossRef] [PubMed]

58. AOAC. Official Methods of Analysis: Association of Official Analytical Chemists; AOAC: Washington, DC, USA, 2000.

59. Skrzypczak, M.; Szwed, A.; Pawlińska-Chmara, R.; Skrzypulec, V. Assessment of the BMI, WHR and W/Ht in pre- and postmenopausal women. Anthropol. Rev. 2007, 70, 3-13. [CrossRef]

60. Friedewald, W.T.; Levy, R.I.; Fredrickson, D.S. Estimation of the Concentration of Low-Density Lipoprotein Cholesterol in Plasma, Without Use of the Preparative Ultracentrifuge. Clin. Chem. 1972, 18, 499-502. [CrossRef] [PubMed]

61. Rodríguez-García, C.; Sánchez-Quesada, C.; Toledo, E.; Delgado-Rodríguez, M.; Gaforio, J.J. Naturally Lignan-Rich Foods: A Dietary Tool for Health Promotion? Molecules 2019, 24, 917. [CrossRef]

62. Guasch-Ferre, M.; Li, J.; Hu, F.B.; Salas-Salvado, J.; Tobias, D.K. Effects of walnut consumption on blood lipids and other cardiovascular risk factors: An updated meta-analysis and systematic review of controlled trials. Am. J. Clin. Nutr. 2018, 108, 174-187. [CrossRef] [PubMed]

63. Moreau, R.A.; Nyström, L.; Whitaker, B.D. Phytosterols and their derivatives: Structural diversity, distribution, metabolism, analysis, and health-promoting uses. Prog. Lipid Res. 2018, 70, 35-61. [CrossRef]

64. Eilat-Adar, S.; Goldbourt, U. Nutritional Recommendations for Preventing Coronary Heart Disease in Women: Evidence Concerning Whole Foods and Supplements. Nutr. Metab. Cardiovasc. Dis. 2010, 20, 459-466. [CrossRef] [PubMed]

65. Mulvihill, E.E.; Huff, M.W. Antiatherogenic Properties of Flavonoids: Implications for Cardiovascular Health. Can. J. Cardiol. 2010, 26 (Suppl. A), 17A-21A. [CrossRef]

66. Brown, M.J.; Ferruzzi, M.G.; Nguyen, M.L.; Cooper, D.A.; Eldringe, A.L.; Schwartz, S.J.; White, W.S. Carotenoid bioavailability is higher from salads ingested with full-fat than with fat-reduced salad dressings as measured with electrochemical detection. Am. J. Clin. Nutr. 2004, 80, 396-403. [CrossRef] [PubMed]

67. Diehr, P.; Beresford, S.A. The relation of dietary patterns to future survival, health, and cardiovascular events in older adults. J. Clin. Epidemiol. 2003, 56, 1224-1235. [CrossRef]

68. Fung, T.T.; Willett, W.C.; Stampfer, M.J.; Manson, J.E.; Hu, F.B. Dietary patterns and the risk of coronary heart disease in women. Arch. Intern. Med. 2001, 161, 1857-1862. [CrossRef] [PubMed]

69. Hu, F.B.; Rimm, E.B.; Stampfer, M.J.; Ascherio, A.; Spiegelman, D.; Willett, W.C. Prospective study of major dietary patterns and risk of coronary heart disease in men. Am. J. Clin. Nutr. 2000, 72, 912-921. [CrossRef]

70. Lichtenstein, A.H.; Appel, L.J.; Brands, M.; Carnethon, M.; Daniels, S.; Franch, H.A.; Franklin, B.; Kris-Etherton, P.; Harris, W.S.; Howard, B.; et al. Diet and lifestyle recommendations revision 2006: A scientific statement from the American Heart Association Nutrition Committee. Circulation 2006, 4, 82-96. [CrossRef] [PubMed]

71. Yang, C.; Wang, B.; Wang, J.; Xia, S.; Wu, Y. Effect of Pyrogallic Acid (1,2,3-Benzenetriol) Polyphenol-Protein Covalent Conjugation Reaction Degree on Structure and Antioxidant Properties of Pumpkin (Cucurbita Sp.) Seed Protein Isolate. LWT 2019, 109, 443-449. [CrossRef]

72. Rezig, L.; Chouaibi, M.; Meddeb, W.; Msaada, K.; Hamdi, S. Chemical Composition and Bioactive Compounds of Cucurbitaceae Seeds: Potential Sources for New Trends of Plant Oils. Process Saf. Environ. Prot. 2019, 127, 73-81. [CrossRef]

73. Meru, G.; Fu, Y.; Leyva, D.; Sarnoski, P.; Yagiz, Y. Phenotypic Relationships among Oil, Protein, Fatty Acid Composition and Seed Size Traits in Cucurbita Pepo. Sci. Hortic. 2018, 233, 47-53. [CrossRef]

74. Chari, K.Y.; Polu, P.R.; Shenoy, R.R. An Appraisal of Pumpkin Seed Extract in 1, 2-Dimethylhydrazine Induced Colon Cancer in Wistar Rats. J. Toxicol. 2018, 2018, 6086490. [CrossRef] [PubMed]

75. Kendall, C.W.; Josse, A.R.; Esfahani, A.; Jenkins, D.J. Nuts, metabolic syndrome and diabetes. Br. J. Nutr. 2010, 104, 465-473. [CrossRef] [PubMed]

76. Rajaei, A.; Barzegar, M.; Mobarez, A.M.; Sahari, M.A.; Esfahani, Z.H. Antioxidant, Anti-Microbial and Antimutagenicity Activities of Pistachio (Pistachia Vera) Green Hull Extract. Food Chem. Toxicol. 2010, 48, 107-112. [CrossRef] [PubMed]

77. Ros, E.; Hu, F.B. Consumption of plant seeds and cardiovascular health: Epidemiological and clinical trial evidence. Circulation 2013, 128, 553-565. [CrossRef]

78. Ostan, R.; Lanzarini, C.; Pini, E.; Scurti, M.; Vianello, D.; Bertarelli, C.; Fabbri, C.; Izzi, M.; Palmas, G.; Biondi, F.; et al. Inflammaging and Cancer: A Challenge for the Mediterranean Diet. Nutrients 2015, 7, 2589-2621. [CrossRef]

79. Alpaslan, M.; Hayta, M. Apricot Kernel: Physical and Chemical Properties. J. Am. Oil Chem. Soc. 2006, 83, 469-471. [CrossRef]

80. Del Gobbo, L.C.; Falk, M.C.; Feldman, R.; Lewis, K.; Mozaffarian, D. Effects of Tree Nuts on Blood Lipids, Apolipoproteins, and Blood Pressure: Systematic Review, Meta-Analysis, and Dose-Response of 61 Controlled Intervention Trials. Am. J. Clin. Nutr. 2015, 102, 1347-1356. [CrossRef]

81. Jenkins, D.J.A.; Kendall, C.W.C.; Marchie, A.; Parker, T.L.; Connelly, P.W.; Qian, W.; Haight, J.S.; Faulkner, D.; Vidgen, E.; Lapsley, K.G.; et al. Dose Response of Almonds on Coronary Heart Disease Risk Factors: Blood Lipids, Oxidized Low-Density Lipoproteins, Lipoprotein (a), Homocysteine, and Pulmonary Nitric Oxide: A Randomized, Controlled, Crossover Trial. Circulation 2002, 106, 1327-1332. [CrossRef] [PubMed] 
82. Zibaeenezhad, M.; Shahamat, M.; Mosavat, S.H.; Attar, A.; Bahramali, E. Effect of Amygdalus Scoparia Kernel Oil Consumption on Lipid Profile of the Patients with Dyslipidemia: A Randomized, Openlabel Controlled Clinical Trial. Oncotarget 2017, 8, 79636-79641. [CrossRef] [PubMed]

83. Zhang, J.; Gu, H.-D.; Zhang, L.; Tian, Z.-J.; Zhang, Z.-Q.; Shi, X.-C.; Ma, W.-H. Protective Effects of Apricot Kernel Oil on Myocardium against Ischemia-Reperfusion Injury in Rats. Food Chem. Toxicol. 2011, 49, 3136-3141. [CrossRef] [PubMed]

84. Jia, X.Y.; Zhang, Q.A.; Zhang, Z.Q.; Wang, Y.; Yuan, J.F.; Wang, H.Y.; Zhao, D. Hepatoprotective Effects of Almond Oil against Carbon Tetrachloride Induced Liver Injury in Rats. Food Chem. 2011, 125, 673-678. [CrossRef]

85. Turan, S.; Topcu, A.; Karabulut, I.; Vural, H.; Hayaloglu, A.A. Fatty Acid, Triacylglycerol, Phytosterol, and Tocopherol Variations in Kernel Oil of Malatya Apricots from Turkey. J. Agric. Food Chem. 2007, 55, 10787-10794. [CrossRef] [PubMed]

86. Fratianni, F.; Ombra, M.N.; d'Acierno, A.; Cipriano, L.; Nazzaro, F. Apricots: Biochemistry and Functional Properties. Curr. Opin. Food Sci. 2018, 19, 23-29. [CrossRef]

87. Zhou, B.; Wang, Y.; Kang, J.; Zhong, J.; Prenzler, P.D. The quality and volatile-profile changes of Longwangmo apricot (Prunus armeniaca L.) kernel oil prepared by different oil-producing processes. Eur. J. Lipid Sci. Technol. 2016, 118, 236-243. [CrossRef]

88. Tanwar, B.; Modgil, R.; Goyal, A. Effect of Detoxification on Biological Quality of Wild Apricot (Prunus Armeniaca L.) Kernel. J. Sci. Food Agric. 2019, 99, 517-528. [CrossRef] [PubMed]

89. Drevon, C.A. Marine Oils and Their Effects. Nutr. Rev. 1992, 50 Pt 2, 38-45. [CrossRef]

90. Sakarkar, D.N.; Deshmukh, V.N. Ethnopharmacological review of traditional medicinal plants for anticancer activity. Int. J. PharmTech Res. 2011, 3, 298-308.

91. Jiagang, D.; Li, C.; Wang, H.; Hao, E.; Du, Z.; Bao, C.; Lv, J.; Wang, Y. Amygdalin Mediates Relieved Atherosclerosis in Apolipoprotein E Deficient Mice through the Induction of Regulatory T Cells. Biochem. Biophys. Res. Commun. 2011, 411, 523-529. [CrossRef] [PubMed]

92. Akbari, G. Molecular mechanisms underlying gallic acid effects against cardiovascular diseases: An update review. Avicenna J. Phytomed. 2020, 10, 11-23. [PubMed]

93. Badhani, B.; Sharma, N.; Kakkar, R. Gallic acid: A versatile antioxidant with promising therapeutic and industrial applications. RSC Adv. 2015, 5, 27540-27557. [CrossRef]

94. Shahrzad, S.; Aoyagi, K.; Winter, A.; Koyama, A.; Bitsch, I. Pharmacokinetics of Gallic Acid and Its Relative Bioavailability from Tea in Healthy Humans. J. Nutr. 2001, 131, 1207-1210. [CrossRef] [PubMed]

95. Ferk, F.; Kundi, M.; Brath, H.; Szekeres, T.; Al-Serori, H.; Mišík, M.; Saiko, P.; Marculescu, R.; Wagner, K.-H.; Knasmueller, S. Gallic Acid Improves Health-Associated Biochemical Parameters and Prevents Oxidative Damage of DNA in Type 2 Diabetes Patients: Results of a Placebo-Controlled Pilot Study. Mol. Nutr. Food. Res. 2018, 62, 1-9. [CrossRef] [PubMed]

96. Chuffa, L.G.A.; Fioruci-Fontanelli, B.A.; Bordon, J.G.; Pires, R.B.; Braga, C.P.; Seiva, F.R.F.; Fernandes, A.A.H. Rutin Ameliorates Glycemic Index, Lipid Profile and Enzymatic Activities in Serum, Heart and Liver Tissues of Rats Fed with a Combination of Hypercaloric Diet and Chronic Ethanol Consumption. Indian J. Biochem. Biophys. 2014, 51, 215-222. [PubMed]

97. Ziaee, A.; Zamansoltani, F.; Nassiri-Asl, M.; Asi, E.A. Effects of Rutin on Lipid Profile in Hypercholesterolaemic Rats. Basic Clin. Pharmacol. Toxicol. 2009, 104, 253-258. [CrossRef] [PubMed]

98. Askari, G.; Yazdekhasti, N.; Mohammadifard, N.; Sarrafzadegan, N.; Bahonar, A.; Badiei, M.; Sajjadi, F.; Taheri, M. The Relationship between Nut Consumption and Lipid Profile among the Iranian Adult Population; Isfahan Healthy Heart Program. Eur. J. Clin. Nutr. 2013, 67, 385-389. [CrossRef] [PubMed]

99. Bes-Rastrollo, M.; Wedick, N.M.; Martinez-Gonzalez, M.A.; Li, T.Y.; Sampson, L.; Hu, F.B. Prospective Study of Nut Consumption, Long-Term Weight Change, and Obesity Risk in Women. Am. J. Clin. Nutr. 2009, 89, 1913-1919. [CrossRef]

100. Bes-Rastrollo, M.; Sabaté, J.; Gómez-Gracia, E.; Alonso, A.; Martínez, J.A.; Martínez-González, M.A. Nut Consumption and Weight Gain in a Mediterranean Cohort: The SUN Study. Obesity 2007, 15, 107-116. [CrossRef]

101. Maruthappan, V.G.; Shree, K.S. Blood cholesterol lowering effect of adenanthera pavonina seed extract on atherogenic diet induced hyperlipidemia in rats. Int. J. Pharm. Sci. Res. 2010, 1, 87-94.

102. Jahromi, M.A.; Ray, A.B. Antihyperlipidemic Effect of Flavonoids from Pterocarpus Marsupium. J. Nat. Prod. 1993, 56, 989-994. [CrossRef]

103. Anum, E.A.; Adera, T. Hypercholesterolemia and coronary heart disease in the elderly: A meta analysis. Ann. Epidemiol. 2004, 14, 705-721. [CrossRef]

104. Iversen, A.; Jensen, J.S.; Scharling, H.; Schnohr, P. Hypercholesterolaemia and risk of coronary heart disease in the elderly: Impact of age: The Copenhagen City Heart Study. Eur. J. Intern. Med. 2009, 20, 139-144. [CrossRef]

105. Gränsbo, K.; Almgren, P.; Nilsson, P.M.; Hedblad, B.; Engström, G.; Melander, O. Risk factor exposure in individuals free from cardiovascular disease differs according to age at first myocardial infarction. Eur. Heart J. 2016, 37, 1977-1981. [CrossRef] [PubMed]

106. Brunner, F.J.; Waldeyer, C.; Ojeda, F.; Salomaa, V.; Kee, F.; Sans, S.; Thorand, B.; Giampaoli, S.; Brambilla, P.; Tunstall-Pedoe, H.; et al. Application of non HDL cholesterol for population based cardiovascular risk stratification: Results from the Multinational Cardiovascular Risk Consortium. Lancet 2019, 394, 2173-2183. [CrossRef]

107. Kopčeková, J.; Kováčiková, E.; Kováčik, A.; Kolesárová, A.; Mrázová, J.; Chlebo, P.; Kolesárová, A. Consumption of Bitter Apricot Seeds Affects Lipid and Endocrine Profile in Women. J. Environ. Sci. Health B 2021, 56, 378-386. [CrossRef] [PubMed] 
108. Cohen, J.C.; Boerwinkle, E.; Mosley, T.H.; Hobbs, H.H. Sequence Variations in PCSK9, Low LDL, and Protection against Coronary Heart Disease. N. Engl. J. Med. 2006, 354, 1264-1272. [CrossRef] [PubMed]

109. Brown, M.S.; Goldstein, J.L. Biomedicine. Lowering LDL-Not Only How Low, but How Long? Science 2006, 311, 1721-1723. [CrossRef] [PubMed]

110. Grundy, S.M.; Cleeman, J.I.; Merz, C.N.B.; Brewer, H.B.; Clark, L.T.; Hunninghake, D.B.; Pasternak, R.C.; Smith, S.C.; Stone, N.J.; Coordinating Committee of the National Cholesterol Education Program. Implications of Recent Clinical Trials for the National Cholesterol Education Program Adult Treatment Panel III Guidelines. Circulation 2004, 110, 227-239. [CrossRef]

111. Katan, M.B.; Grundy, S.M.; Jones, P.; Law, M.; Miettinen, T.; Paoletti, R.; Stresa Workshop Participants. Efficacy and Safety of Plant Stanols and Sterols in the Management of Blood Cholesterol Levels. Mayo Clin. Proc. 2003, 78, 965-978. [CrossRef]

112. Padro, T.; Muñoz-Garcia, N.; Badimon, L. The Role of Triglycerides in the Origin and Progression of Atherosclerosis. Clin. Investig. Arterioscler. 2021, 33 (Suppl. 2), 20-28. [CrossRef]

113. Mortensen, M.B.; Nordestgaard, B.G. Elevated LDL cholesterol and increased risk of myocardial infarction and atherosclerotic cardiovascular disease in individuals aged 70-100 years: A contemporary primary prevention cohort. Lancet 2020, 21, 1644-1652. [CrossRef]

114. Talebi, S.; Bagherniya, M.; Atkin, S.L.; Askari, G.; Orafai, H.M.; Sahebkar, A. The Beneficial Effects of Nutraceuticals and Natural Products on Small Dense LDL Levels, LDL Particle Number and LDL Particle Size: A Clinical Review. Lipids Health Dis. 2020, 19, 66. [CrossRef]

115. Pascot, A.; Lemieux, I.; Prud'homme, D.; Tremblay, A.; Nadeau, A.; Couillard, C.; Bergeron, J.; Lamarche, B.; Després, J.P. Reduced HDL Particle Size as an Additional Feature of the Atherogenic Dyslipidemia of Abdominal Obesity. J. Lipid Res. 2001, 42, 2007-2014. [CrossRef]

116. St-Pierre, A.C.; Cantin, B.; Dagenais, G.R.; Mauriège, P.; Bernard, P.M.; Després, J.P.; Lamarche, B. Low-density lipoprotein subfractions and the long-term risk of ischemic heart disease in men: 13-year follow-up data from the Québec Cardiovascular Study. Arterioscler. Thromb. Vasc. Biol. 2005, 25, 553-559. [CrossRef] [PubMed]

117. Lamarche, B.; Tchernof, A.; Moorjani, S.; Cantin, B.; Dagenais, G.R.; Lupien, P.J.; Després, J.P. Small, Dense Low-Density Lipoprotein Particles as a Predictor of the Risk of Ischemic Heart Disease in Men. Prospective Results from the Québec Cardiovascular Study. Circulation 1997, 95, 69-75. [CrossRef] [PubMed]

118. Patti, A.M.; Al-Rasadi, K.; Giglio, R.V.; Nikolic, D.; Mannina, C.; Castellino, G.; Chianetta, R.; Banach, M.; Cicero, A.F.; Lippi, G. Natural approaches in metabolic syndrome management. Arch. Med. Sci. 2018, 14, 422-441. [CrossRef] [PubMed]

119. Cicero, A.F.; Colletti, A.; Bajraktari, G.; Descamps, O.; Djuric, D.M.; Ezhov, M.; Fras, Z.; Katsiki, N.; Langlois, M.; Latkovskis, G. Lipid-lowering nutraceuticals in clinical practice: Position paper from an international lipid expert panel. Nutr. Rev. 2017, 75, 731-767. [CrossRef]

120. Sahebkar, A.; Serban, M.C.; Gluba-Brzozka, A.; Mikhailidis, D.P.; Cicero, A.F.; Rysz, J.; Banach, M. Lipid-modifying effects of nutraceuticals: An evidence-based approach. Nutrition 2016, 32, 1179-1192. [CrossRef] [PubMed]

121. Scicchitano, P.; Cameli, M.; Maiello, M.; Modesti, P.A.; Muiesan, M.L.; Novo, S.; Palmiero, P.; Saba, P.S.; Pedrinelli, R.; Ciccone, M.M. Nutraceuticals and dyslipidaemia: Beyond the common therapeutics. J. Funct. Foods 2014, 6, 11-32. [CrossRef]

122. Mannarino, M.R.; Ministrini, S.; Pirro, M. Nutraceuticals for the treatment of hypercholesterolemia. Eur. J. Intern. Med. 2014, 25, 592-599. [CrossRef] [PubMed]

123. Holligan, S.D.; West, S.G.; Gebauer, S.K.; Kay, C.D.; Kris-Etherton, P.M. A moderate-fat diet containing pistachios improves emerging markers of cardiometabolic syndrome in healthy adults with elevated LDL levels. Br. J. Nutr. 2014, 112, 744-752. [CrossRef] [PubMed]

124. Yucesan, F.B.; Orem, A.; Kural, B.V.; Orem, C.; Turan, I. Hazelnut consumption decreases the susceptibility of LDL to oxidation, plasma oxidized LDL level and increases the ratio of large/small LDL in normolipidemic healthy subjects. Anadolu Kardiyol. Derg. 2010, 10, 28-35. [CrossRef] [PubMed]

125. Almario, R.U.; Vonghavaravat, V.; Wong, R.; Kasim-Karakas, S.E. Effects of walnut consumption on plasma fatty acids and lipoproteins in combined hyperlipidemia. Am. J. Clin. Nutr. 2001, 74, 72-79. [CrossRef]

126. Zitnanova, I.; Oravec, S.; Janubova, M.; Konarikova, K.; Dvorakova, M.; Laubertova, L.; Kralova, M.; Simko, M.; Muchova, J. Gender differences in LDL and HDL subfractions in atherogenic and nonatherogenic phenotypes. Clin. Biochem. 2020, 79, 9-13. [CrossRef]

127. Oravec, S.; Dukat, A.; Gavornik, P.; Kucera, M.; Gruber, K.; Gaspar, L.; Rizzo, M.; Toth, P.P.; Mikhailidis, D.P.; Banach, M. Atherogenic versus non-atherogenic lipoprotein profiles in healthy individuals. Is there a need to change our approach to diagnosing dyslipidemia? Curr. Med. Chem. 2014, 21, 2892-2901. [CrossRef] [PubMed]

128. Rajman, I.; Kendall, M.J.; Cramb, R.; Holder, R.L.; Salih, M.; Gammage, M.D. Investigation of Low Density Lipoprotein Subfractions as a Coronary Risk Factor in Normotriglyceridaemic Men. Atherosclerosis 1996, 125, 231-242. [CrossRef]

129. Eyidemir, M.; Hayta, M. The effect of apricot kernel flour incorporation on the physicochemical and sensory properties of noodle. Afr. J. Biotechnology. 2009, 8, 85-90.

130. Demir, A.D.; Cronin, K. Modelling the kinetics of textural changes in hazelnuts during roasting. Simul. Model. Pract. Theory 2005, 13, 97-107. [CrossRef] 